\title{
Species composition, plant cover and diversity of recently reforested wild lands near Dabao Highway in Longitudinal Range-Gorge Region of Yunnan Province, China
}

\author{
Dong, S. K.*, Cui, B. S., Yang, Z. F., Liu, S. L., Liu, J., Wang, J., Ding, Z. K., Gao, L. N. and \\ Zhao, S. Q. \\ Environmental School of Beijing Normal University, Beijing, 100875, China.
}

Accepted 22 November, 2007

\begin{abstract}
Deforestation, over-cultivation and rural growth have severely damaged native vegetation of woodlands along roadsides in the Longitudinal Range-Gorge Region of Yunnan Province. This study was conducted to evaluate the effect of different reforestation practices, which consisted of natural restoration or planting with tree seedlings that varied in species composition, coverage and diversity, on damaged roadside woodlands. Three randomly selected $10 \mathrm{~m} \times 10 \mathrm{~m}$ plots in each reforestation practice were investigated. The results showed that the species composition, plant cover and species diversity of the planted communities varied with reforestation strategies and time since planting. A higher number of species, proportion of native species and woody plants, canopy cover and species diversity were found in naturally restored plots and in $3-4$ year old plots that were planted with native plants. In the early stages of reforestation, herbs dominated the plant community in most plots, and woody plants became more important with time after reforestation. Preliminary results suggest that plant height can be used an auxiliary indicator of plant cover to assess ecosystem function status of the restoration project. Also, evenness may be easier to restore than species richness. Natural restoration or reforestation with native dominant plants is a good management strategy for vegetation restoration or improvement.
\end{abstract}

Key words: Vegetative characteristics, plant community, restoration, Southwest China.

\section{INTRODUCTION}

Land degradation, due to the root causes of overpopulation, poverty and lack of enforceable policies and reasonable management measures, is a worldwide environmental problem limiting the sustainable development of global society (Sisk et al., 1994; McCracken and Abaza, 2001; Reynolds and Smith, 2002; World Bank, 2002). Degraded ecosystems, with damaged biotic components, have diminished control over resources such as soil nutrients and water resources (Davenport et al., 1998). Seriously damaged lands not only lose control over resources, but also lose the capacity for self-repair and are unable to prevent additional degradation (Whisenant, 1999). Thus, they are less resilient to addi-

*Corresponding author. E-mail: dongshikui@sina.com. tional stress or damage and provide fewer environmental services (Myers, 1996). As these degrading processes continue, a threshold can be crossed exceeding the ability for the ecosystem to recover and desertification results, a dynamic and self-perpetuating process (Tivy, 1990; Thurow, 1991).

Since the early 1980s, China has achieved remarkable agricultural and rural growth with the de-collectivization of agriculture, which greatly reduced poverty but addressed many environmental problems such as resource loss and land degradation (Wang, 1999; Wang and Gao, 2001). The Longitudinal Range-Gorge Region of Yunnan Province, Southwest China is an example of a region which has been severely affected by agricultural decollectivization (Peng and Wang, 2005), especially in the sites along the roadsides (Wang and Shi, 2001; Zhao, 2006). With excessive biomass removal and continued 
Table 1. Reforestation practices and sites description.

\begin{tabular}{|c|l|c|c|c|c|c|c|}
\hline $\begin{array}{c}\text { Reforest } \\
\text { practices }\end{array}$ & \multicolumn{1}{|c|}{ Plantings } & $\begin{array}{c}\text { Reforest } \\
\text { year }\end{array}$ & $\begin{array}{c}\text { Distance to } \\
\text { road }(\mathrm{m})\end{array}$ & Aspect & Slope & $\begin{array}{c}\text { Soil } \\
\text { type }\end{array}$ & $\begin{array}{c}\text { Soil } \\
\text { moisture }\end{array}$ \\
\hline I & Eucalyptus maideni & 2004 & $300-500$ & $\mathrm{~S}$ & 12 & clay & $35 \%$ \\
II & Pinus yunnanensis & 2004 & $500-700$ & $\mathrm{~S}$ & 13 & clay & $30 \%$ \\
III & Alnus nepalensis & 2002 & $800-1000$ & $\mathrm{~S}$ & 12 & clay & $38 \%$ \\
& and & & & & & & \\
& Pinus yunnanensis & & & & & & \\
IV & Pinus yunnanensis & 2002 & $400-500$ & SE & 11 & clay & $28 \%$ \\
V & Pinus yunnanensis & 1999 & $600-800$ & SE & 13 & clay & $32 \%$ \\
VI & Pinus yunnanensis & 1994 & $150-200$ & SE & 15 & clay & $35 \%$ \\
VII & None & 2002 & $200-300$ & SE & 10 & clay & $26 \%$ \\
VIII & None & 2004 & $900-1000$ & SE & 12 & clay & $25 \%$ \\
\hline
\end{tabular}

over-cultivation, plant populations changed, and biological diversity and productivity decreased. Continued reductions in plant productivity decreased litter and vegetative cover, which in turn increased erosion and desertification (He, 1991; Gao, 2003). Vegetation conservation and restoration in this region is becoming a significant regional and national concern (Liu et al., 2002). Presently, these lands are the focus of woodland forest restoration efforts by the local government (Liu, 2005).

An increasingly common goal of ecosystem restoration is to restore the high levels of plant species, traits and functional groups similar to that found in remnant sites (Pywell et al., 2003; Smith et al., 2003). However, no sites remain that can serve as a reference woodland forest for restoration in this region due to severe disturbance from agricultural production and rural development activities in the past. Most of the degraded lands have been reforested recently under one of China's National Ecological Construction Plans, "Returning Agricultural Land to Forest Land", which was established in 1999. Given the importance of colonization on forest stand composition and species spatial patterns (Oliver and Larson, 1996), evaluation of early restoration efforts on marginal agricultural lands is critical to assess the value of reforestation efforts and to aid in the planning of future plantings (Kruse and Groninger, 2003). In this sense, this study was proposed to evaluate the early success of different reforestation efforts.

Restoring community structure (e.g. species composi-tion and diversity) and ecosystem processes typically are listed as the two main objectives of restoration and vegetation improvement (Palmer et al., 1997; Lockwood and Pimm, 1999; Smith et al., 2000). Some researchers Bradshaw (1996), Hobbs and Norton (1996), and Martin et al. (2005) have proposed that the proportion of native species and plant diversity at all spatial scales are the criteria that should be used to evaluate the success of restoration efforts. We focus on these two criteria- the ratio of native plants in the species composition, and plant diversity at the site scale to to evaluate the success of reforestation projects implemented in recent years along the roadside of the Dabao Highway, Longitudinal Range-Gorge Region of Yunan Province, China. The overall goal of this study was to evaluate the effect of different reforestation practices on woodlands damaged by agricultural production and rural development, which included natural restoration and planting with different tree seedlings at different times before this survey on species composition, cover and diversity.

\section{MATERIALS AND METHODS}

\section{Study site}

The study site is situated beside the Laoying exit of Dabao Hingway, Longitudinal Range-Gorge Region of Yunan Province, China (N2519', E9912', 1836 m a.s.I.), a subtropical region, where reforestation projects were initiated in 1994 for restoring wildlands and the former evergreen woodland. Within the study site, there were 8 reforestation practices (RP) shown in Table 1. All RPs have been implemented on neighboring plots within the study site. Environmental characteristics of the plots of different RP, including location, aspect, slope, soil type and moisture, were recorded before the vegetation investigation (Table 1). Vegetation surveys were conducted in 2004 and 2005.

\section{Sampling methods}

Field investigations and sampling were conducted in October to November, when most of evergreen vegetation was still growing but past the rainy season. At the beginning of investigation, all plants species within each reforestation plot were identified and species composition (total number, life form, native plant ratio) were quantified. Species were classified into different functional groups based on their growth form: trees, shrubs and herbs (Polley et al., 2005). Quantitative characteristics of the vegetation including cover, height, number of individual species, functional groups and plant community were investigated in three $10 \mathrm{~m} \times 10 \mathrm{~m}$ quadrats which were randomly placed in each RP plot. Simpson's diversity index, Marglef's richness index, and the Pielou evenness index were calculated following the formulas cited by Dong (1997). 


\section{Statistical analysis}

Species composition, canopy cover, plant height, species diversity, richness and evenness of the plant communities and functional groups under each RP are presented as the means of three replicates. The effects of RP on vegetation characteristics were analyzed via ANOVA using a Generalized Liner Model of SPSS 10.0 (Huang et al., 2001).

\section{RESULTS}

\section{Species composition of plant communities}

There were a total of 69 species in the study site, with 4 exotic and 65 native species, 16 trees, 15 shrubs and 38 herb species (Table 2). In individual RP plots, there was a total of 1 species in RPI, 33 in RPII, 24 in RPIII, 15 in RPIV, 25 in RPV, 15 in RPVI, 33 in RPVII and 16 in RPVIII.

The species compositions of plant communities in the different RP varied greatly (Table 3 ). The plant community of RPI consisted of one species, the exotic tree, Eucalyptus maideni, a commercial tree imported from Southeast Asia. The community in RPII had a high species number (33, ranked 2nd of all plots), a relatively high proportion of exotic plants (12.1\%), and the same proportion of tree and shrub species (18.2\%). In RPIII, there were 24 plant species, with $91.7 \%$ native and $8.3 \%$ exotic species, and most species were herbs (62.6\%). In RPIV, there were only 15 species ( 3 trees, 6 shrubs and 6 herbs) but a high proportion of these were exotic species (13.3\%). The plant community of RPV was composed of 25 species, $92.0 \%$ of which were native species, and $12 \%$ were trees, $40 \%$ shrubs and $48 \%$ herbs. The plant community in RPVI had the highest proportion of both native species (93.3\%) and trees (33.3\%) among all plots, although the total number of species (15) was comparatively low. The plant community in RPVII had 33 species, the highest number among all plots, and had similar proportions of trees and shrubs. The plant community of RPVIII had only 12 species with a very high proportion of herbs $(69.2 \%)$.

The results showed that the species composition varied with reforestation strategy and time. The RPI plots were replanted with $\mathrm{E}$. maideni and produced a single-species community, as native plants can not co-exist with this fast-growing and shady tree. Plots of RPVI were replanted with the native trees, Pinus yunnanensis and Lyonia ovalifolia, and RPVII was naturally restored, both of which had more native species and trees in their species composition. Although the plot of RPIV was replanted with the native tree, P. yunnanensis, there was a low total number of species and a high proportion of exotic plants in the composition. In all replanted plots except RPI, the plant communities reached the highest number of species at the beginning of reforestation. In naturally restored plots, the highest species numbers were observed in the third or fourth growing year. A greater proportion of herbs were found in the early years following restoration. The proportion of shrubs increased with time following restoration after 4 - 5 years.

\section{Vegetative characteristics of the plant communities}

Table 4 shows that the RPI plot had complete plant cover with plant heights of $4.83 \mathrm{~m}$, indicating RPI had the highest $(P<0.05)$ coverage and height among all RPs. The plant community of RPVI was ranked second in terms of both canopy coverage (95\%) and height (3.60 $\mathrm{m})$. Although the canopy coverage of RPIII and RPV was not different than RPVI, their canopy height was significantly lower $(P<0.05)$. Canopy coverage in RPII, RPIV and RPVII was similarly low (around $85 \%$ ), but canopy height of RPII was significantly higher $(P<0.05)$ than the latter two. Canopy cover $(70 \%)$ and height $(0.40$ $\mathrm{m})$ of RPVIII was the lowest $(\mathrm{P}<0.05)$ among all RPs.

Species richness, evenness and diversity of plant community greatly varied with the restoration practice and time (Table 4). Species richness index, species diversity index and species evenness index varied from $4.27-0.22,0.74-0$ and 0.62 - 0 , respectively. The RPVII plot was highest $(P<0.05)$ in species richness among all plots. Species richness was significantly different ( $P$ $>0.05$ ) among RPII, PRIII, PRIV, PRVI and PRVIII plots. In general, species diversity in the plots of RPIII, PRVI and PRVII was relatively high while those in the plots of RPII, RPIV, RPV and RPVIII were low in species diversity. In terms of species evenness, plant communities in the plots of RPIII and PRVI were higher $(\mathrm{P}<0.05)$ than those in the plots of RPII, RPIV, RPV and RPVIII, and RPVII was not significantly different from plots RPII, RPV, RPVI and RPVIII. The single species community of RPI was extremely low in species richness (0.22), diversity (0) and evenness (0).

\section{Vegetative characteristics of functional groups}

Percent cover of the different functional groups (tree, shrub and herb) in the different reforestation plots are presented in Figure 1. Generally, herbs had a higher plant cover than shrubs in all plots except for RPI, and the percent cover of trees varied greatly from plot to plot. The dominant plant functional groups in the reforested plots in this study were either trees or herbs. As for different reforestation practices, RPI was the highest in the percent tree cover (95\%) and RPVIII had zero percent cover of trees. RPII was higher $(P<0.05)$ than others in the shrub cover, whereas RPI had zero percent shrub cover. RPVII was significantly highest in the percent cover of herbs (around 80\%) and RPI had no herbs.

Species richness varied with functional groups and reforestation practice (Figure 2). Species richness of herbs was generally higher than shrubs and trees under 
Table 2. Species identified in the plots of different reforestation practices.

\begin{tabular}{|c|c|c|c|c|c|c|c|c|c|c|}
\hline Species & Native/Exotic & Life form & 1 & II & III & IV & v & VI & VII & VIII \\
\hline Eucalyptus maideni & Exotic & Tree & + & & & & & & & \\
\hline Ternstroemia gymnanthera & Native & Tree & & & & & & & + & \\
\hline Pinus yunnanensis & Native & Tree & & & + & + & + & + & & \\
\hline Pinus kesiya var. langbianensis & Native & Tree & & + & & & & & & \\
\hline Pinus armandii & Exotic & Tree & & & & & & & + & \\
\hline Alnus nepalensis & Native & Tree & & + & + & & & & & \\
\hline Viburnum ylindricum & Native & Tree & & & & & + & & + & \\
\hline Dalbergia minosoides & Native & Tree & & & & & & & + & \\
\hline Populus yunnanensis & Native & Tree & & & & & & & + & \\
\hline Betula alnoides & Native & Tree & & & & & & & + & \\
\hline Juglans regia & Native & Tree & & + & & & & & & \\
\hline Desmodium sequax & Exotic & Tree & & + & & & & & & \\
\hline Lyonia ovalifolia & Native & Tree & & + & + & + & & + & & \\
\hline Rubus pectinellus & Native & Tree & & + & & & + & + & + & + \\
\hline Corylus chinensis & Native & Tree & & & & & & + & & \\
\hline Lindera caudata & Native & Tree & & & & + & & + & & \\
\hline Artemisia subdigitata & Native & Shrub & & + & + & + & + & & & \\
\hline Vaccinium fragile & Native & Shrub & & + & & & + & + & & \\
\hline Elsholtzia fruticosa & Native & Shrub & & + & + & + & + & + & + & + \\
\hline Inula cappa & Native & Shrub & & + & & + & + & + & + & + \\
\hline Indigofera stachyoides & Native & Shrub & & + & + & & & & & \\
\hline Hypericum patulum & Native & Shrub & & + & + & + & + & + & + & + \\
\hline Kummerowia striata & Native & Shrub & & & + & & + & & + & \\
\hline Rubus ellipticus var. obcordatus & Native & Shrub & & & + & & + & & + & \\
\hline Dioscores sp. & Native & Shrub & & & & & + & & & \\
\hline Triumfetta rhomboidea & Native & Shrub & & & & & + & & & \\
\hline Melastoma normale & Native & Shrub & & & & & & & + & \\
\hline Elaeagnus stellipila & Native & Shrub & & & & + & + & & + & \\
\hline Rosa cymosa & Native & Shrub & & & & + & & & & \\
\hline Lespedeza fornosa & Native & Shrub & & & & & & & + & \\
\hline Isachne albens & Native & Herbage & & + & + & & + & + & + & + \\
\hline Bidens pilosa & Native & Herbage & & + & & & & & & \\
\hline Setaria viridis & Native & Herbage & & + & & & & & & \\
\hline Digitaria ciliaria & Native & Herbage & & + & & & + & & + & + \\
\hline Carpesium cernuum & Native & Herbage & & & & & + & & + & + \\
\hline Adenostemma lavenia & Native & Herbage & & + & & & & & & \\
\hline Centotheca lappacea & Native & Herbage & & + & & & & & & \\
\hline Notochaete hamosa & Native & Herbage & & + & & & & & + & \\
\hline Cyperus ollingeri & Native & Herbage & & + & + & & & & & \\
\hline Cynodon dactylon & Native & Herbage & & + & & & & & & \\
\hline Centella asiatica & Native & Herbage & & + & + & + & & & + & \\
\hline Oxalis corniculata & Native & Herbage & & + & + & & & & & \\
\hline Eupatorium coelestinum & Exotic & Herbage & & + & + & + & + & + & & + \\
\hline Veronica didyma & Native & Herbage & & & + & + & & & + & \\
\hline Miscanthus sinensis & Native & Herbage & & & + & & & & & \\
\hline Dicranopteris dichotoma & Native & Herbage & & & & & & + & & \\
\hline Erigeron elongatus & Exotic & Herbage & & + & + & + & + & & + & \\
\hline Clinopodium chinens & Native & Herbage & & & & & & & + & \\
\hline Imperata cylindrica var. major & Native & Herbage & & & + & & & + & & \\
\hline Melasma arvense & Native & Herbage & & + & & & & & & + \\
\hline Sagina japonica & Native & Herbage & & + & & & & & & \\
\hline
\end{tabular}


Table 2. Contd.

\begin{tabular}{|c|c|c|c|c|c|c|c|c|c|c|}
\hline Eulalia speciosa & Native & Herbage & & + & + & & + & + & & \\
\hline Glyceria acutiflora & Native & Herbage & & & & & & + & & \\
\hline Anaphalis margaritacea & Native & Herbage & & + & + & & + & & + & + \\
\hline Gonostegia hirta & Native & Herbage & & + & + & & & & & \\
\hline Potentilla anserina & Native & Herbage & & + & + & & + & & + & \\
\hline Gnaphalium hypoleucuma & Native & Herbage & & & & & & & + & \\
\hline Viola philippica & Native & Herbage & & & & & & & + & \\
\hline Ainsliaea henry & Native & Herbage & & & & & + & & + & + \\
\hline Panicum brevifolium & Native & Herbage & & & & + & + & & + & \\
\hline Gentiana rhodantha & Native & Herbage & & & & & & & + & \\
\hline Eleusine indica & Native & Herbage & & & & + & + & & + & \\
\hline Verbena officinalis & Native & Herbage & & & & & & & + & \\
\hline Viola principis & Native & Herbage & & & & & & & + & \\
\hline Carex balcans & Native & Herbage & & & & & + & & & \\
\hline Ixeris denticulata & Native & Herbage & & + & + & & & & & \\
\hline Valeriana hardwickii & Native & Herbage & & & + & & & & & \\
\hline Poa annua & Native & Herbage & & & & & & & & + \\
\hline Trollius ranunculoides & Native & Herbage & & + & & & & & & \\
\hline Total number & 69 & 69 & 1 & 33 & 24 & 15 & 25 & 15 & 33 & 12 \\
\hline
\end{tabular}

Table 3. Species compositions of vegetation under different restoration practices.

\begin{tabular}{|c|c|c|c|c|c|c|c|}
\hline \multirow{2}{*}{$\begin{array}{l}\text { Reforestation } \\
\text { practices }\end{array}$} & \multirow{2}{*}{$\begin{array}{l}\text { Physical } \\
\text { vegetation }\end{array}$} & \multirow[b]{2}{*}{ Dominant species } & \multicolumn{2}{|c|}{$\begin{array}{c}\text { Proportion of native } \\
\text { plant (\%) }\end{array}$} & \multicolumn{3}{|c|}{$\begin{array}{c}\text { Proportion of plant life form } \\
(\%)\end{array}$} \\
\hline & & & Native & Exotic & Tree & Shrub & Herbage \\
\hline I & Forestry & Eucalyptus maideni & 0 & 100 & 100 & 0 & 0 \\
\hline II & Shrubland-like & Pinus yunnanensis & 87.9 & 12.1 & 18.2 & 18.2 & 63.6 \\
\hline III & Forestry & $\begin{array}{l}\text { Pinus yunnanensis } \\
\text { And Alnus nepalensis }\end{array}$ & 91.7 & 8.3 & 12.5 & 25 & 62.5 \\
\hline IV & Shrubland -like & Pinus yunnanensis & 86.7 & 13.3 & 20 & 40 & 40 \\
\hline $\mathrm{V}$ & Forestry & Pinus yunnanensis & 92.0 & 8.0 & 12 & 40 & 48 \\
\hline VI & Forestry & $\begin{array}{l}\text { Pinus yunnanensis and } \\
\text { Lyonia ovalifolia }\end{array}$ & 93.3 & 6.7 & 33.3 & 26.7 & 40 \\
\hline VII & Shrubland & $\begin{array}{l}\text { Hypericum patulum and } \\
\text { Elsholtzia fruticosa }\end{array}$ & 91.7 & 8.3 & 27.8 & 22.2 & 50 \\
\hline VIII & Grassland & Eupatorium coelestinum & 92.3 & 7.7 & 7.7 & 23.1 & 69.2 \\
\hline
\end{tabular}

Table 4. Vegetative characteristics of plant communities under different restoration practices.

\begin{tabular}{|c|c|c|c|c|c|}
\hline Reforestation practices & $\begin{array}{c}\text { Canopy } \\
\text { coverage (\%) }\end{array}$ & $\begin{array}{c}\text { Canopy } \\
\text { height (m) }\end{array}$ & Species richness & Species diversity & Species evenness \\
\hline 1 & $100 \pm 0 a$ & $4.83 \pm 0.39 a$ & $0.22 \pm 0 c$ & $0 \mathrm{e}$ & $0 \mathrm{e}$ \\
\hline II & $80 \pm 5.0 c$ & $1.27 \pm 0.23 d$ & $3.19 \pm 0.66 b$ & $0.57 \pm 0.14 \mathrm{~cd}$ & $0.39 \pm 0.4 \mathrm{~cd}$ \\
\hline III & $91.7 \pm 5.0 \mathrm{~b}$ & $2.20 \pm 0.44 c$ & $3.18 \pm 0.45 b$ & $0.73 \pm 0.11 \mathrm{ab}$ & $0.62 \pm 0.14 a$ \\
\hline IV & $80 \pm 5.0 c$ & $0.90 \pm 0.17 \mathrm{de}$ & $2.97 \pm 0.12 b$ & $0.52 \pm 0.06 d$ & $0.38 \pm 0.03 d$ \\
\hline V & $96.0 \pm 1.7 b$ & $2.07 \pm 0.31 \mathrm{c}$ & $3.04 \pm 0.57 b$ & $0.58 \pm 0.06 \mathrm{~cd}$ & $0.42 \pm 0.09 \mathrm{~cd}$ \\
\hline VI & $95 \pm 0 b$ & $3.60 \pm 0 b$ & $3.26 \pm 0 b$ & $0.74 \pm 0 a$ & $0.58 \pm 0 a b$ \\
\hline VII & $83 \pm 3.6 c$ & $0.63 \pm 0.21 \mathrm{ef}$ & $4.27 \pm 1.07 a$ & $0.67 \pm 0.06 \mathrm{abc}$ & $0.50 \pm 0.08 \mathrm{bc}$ \\
\hline VIII & $70 \pm 0 d$ & $0.40 \pm 0 f$ & $2.82 \pm 0 \mathrm{~b}$ & $0.61 \pm 0 \mathrm{bcd}$ & $0.46 \pm 0 \mathrm{~cd}$ \\
\hline
\end{tabular}




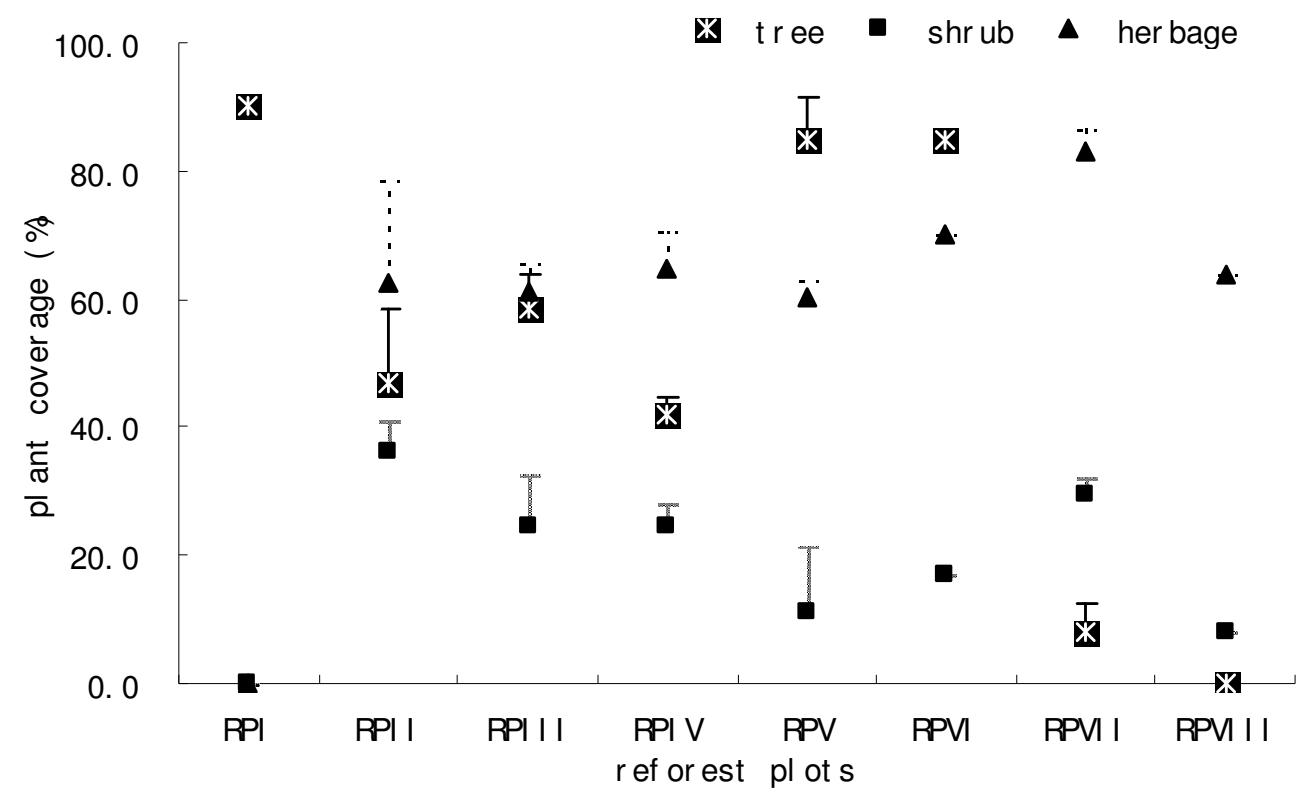

Figure 1. Percent coverage of functional plant groups in different reforest plots.

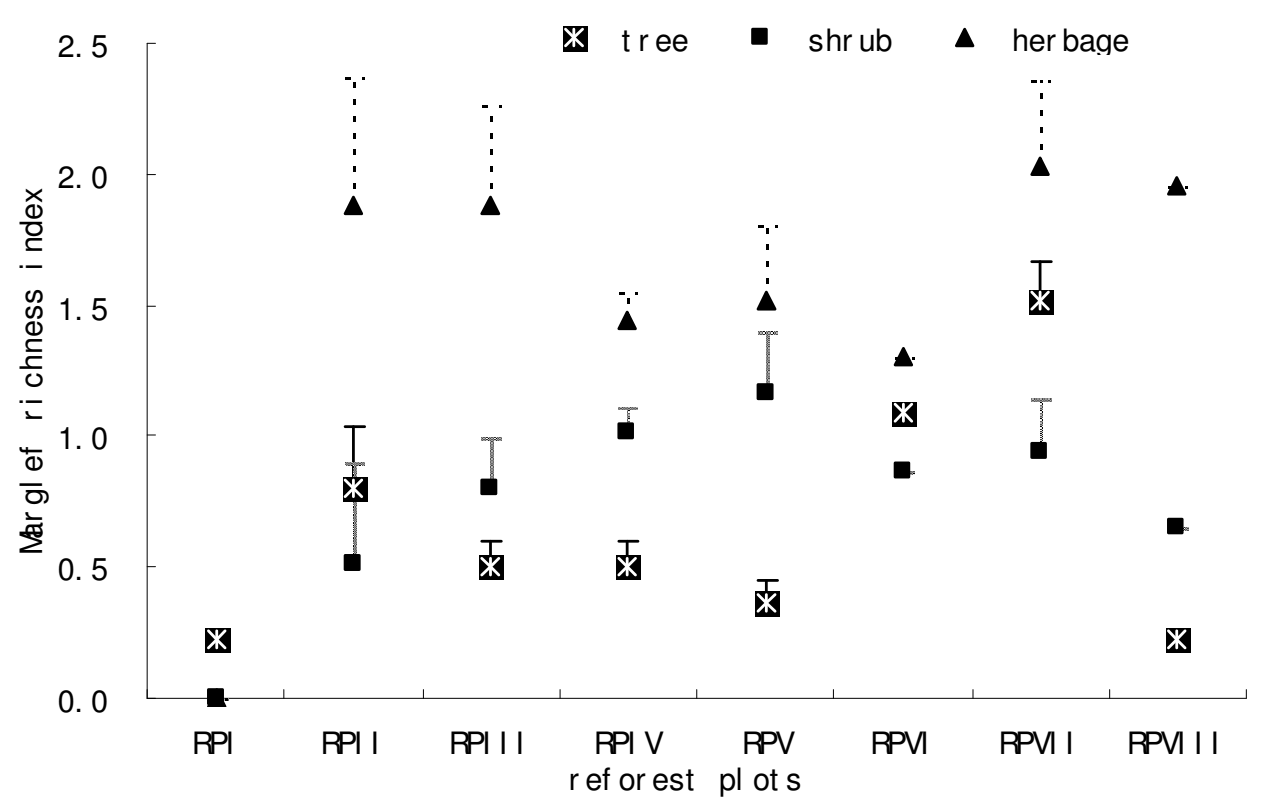

Figure 2. Special richness of functional plants groups in different reforest plots.

the same reforestation strategy, except for RPI. Species richness of the shrub group was higher than species richness of trees under reforestation practices RPIII, RPIV, RPV and RPVIII but lower under remaining reforest practices. Species richness of trees was as low as 0.22 in RPI and RPVIII plots, meaning only one tree species per $100 \mathrm{~m} 2$, while it was as high as 1.52 while in RPVIII plot, meaning 7 tree species per $100 \mathrm{~m} 2$. Species richness of shrubs was highest (1.21) and lowest (0) under RPV and RPI reforestation practices, respectively.
Species richness of herbs was greater than 1.30 under all reforestation practices except for RPI, meaning there were more than 6 herb species per $100 \mathrm{~m} 2$.

There was great variation in species evenness among both functional groups and reforestation strategies (Figure 3). Under reforestation practices of RPII, RPIII and RPVII, tree evenness was highest, shrub lowest and herbs were in between. Under RPV and RPVIII, evenness of shrubs was highest; trees, lowest and herbs, medium. Under RPIV and RPVI, herb evenness was 


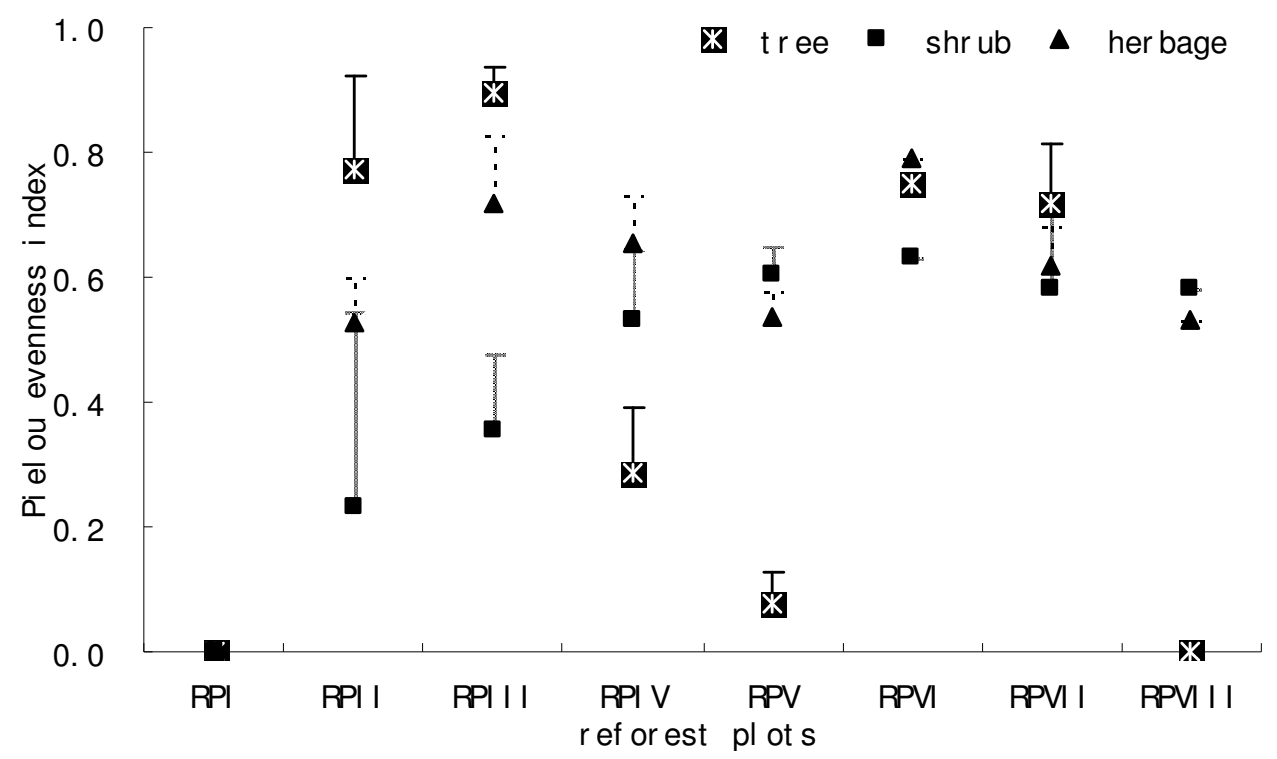

Figure 3. Special evenness of functional plant groups in different reforest plots.

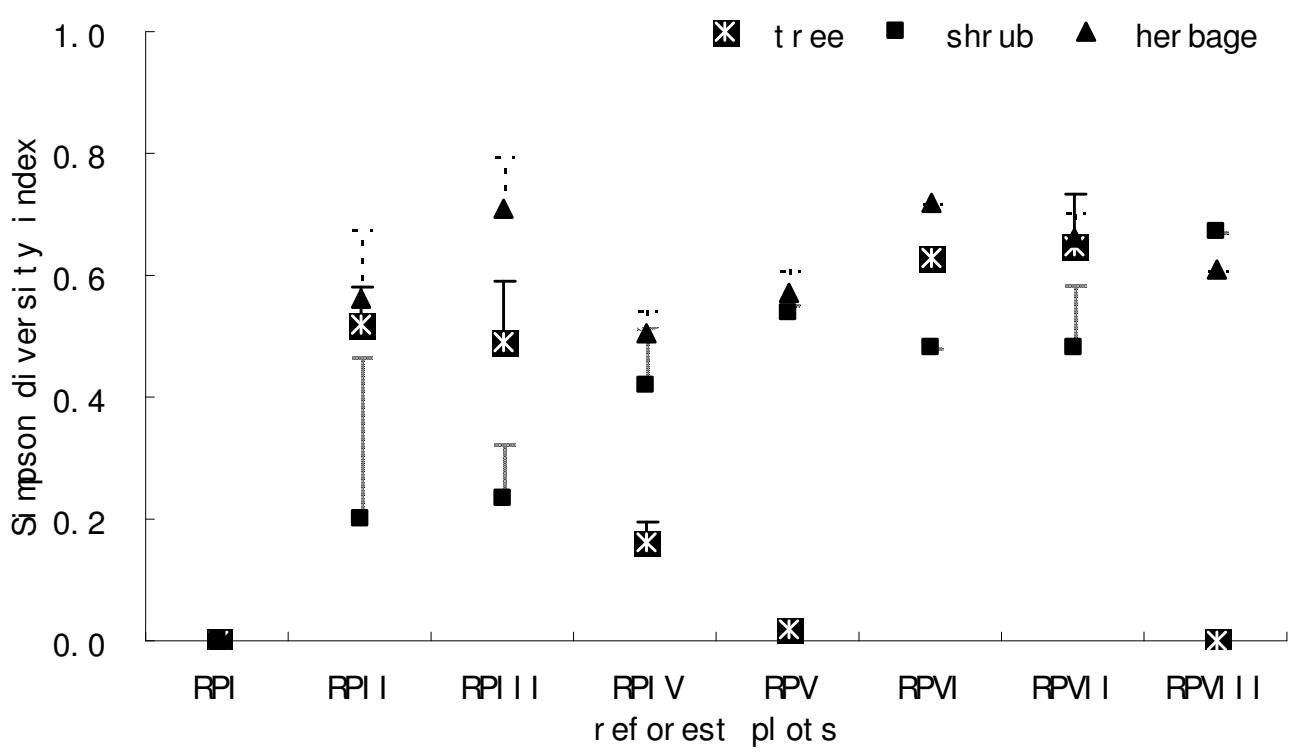

Figure 4. Special diversity of functional plant groups in different reforest plots.

highest. Under RPI, all functional groups had species evenness of zero. The highest species evenness for trees $(0.90)$ was observed in RPIII plot, and zero species evenness of trees was found in RPVIII plots. Shrub reached the highest species evenness $(0.65)$ under RPV, and herbs were highest in species evenness $(0.70)$ under RPIII.

Species diversity also varied greatly with both functional groups and reforestation strategy (Figure 4). Herb diversity was highest; shrub, lowest and trees, medium under reforest practices of RPII, RPIII and RPVI. Herb diversity was highest; shrubs, medium; tree diver- sity, lowest under RPIV. Herb and shrub diversity was equal and tree diversity was zero under RPV. Species diversity of herbs and trees was similar and both higher than shrub diversity under RPVII. Species diversity of shrubs was highest among the three functional groups and that tree diversity was zero under RPVIII. Under RPI, all functional groups had a species diversity of zero. The highest species diversity of trees (0.65) was observed in RPVII plot, and zero species diversity of trees was found in RPVIII plot. Shrub diversity was highest in RPVIII (0.70), and herb diversity was highest in RPIII and RPVI (0.75). 


\section{DISCUSSION}

Ecosystem restoration is becoming a common way of bringing back native species and their habitats. Although studies of restoration success for native vegetation are still few in number, a common conclusion emerged from many studies on different ecosystems (Wilkins et al., 2003). Seedlings of multiple species are expected to emerge, survive and establish reproducing populations, and then populations are expected to assemble into a community similar to the original system (Martin and Milsey, 2006). Restoring community structure (that is, species composition and diversity), one of the two main objectives of restoration and vegetation improvement, was stressed in the current study to quantitatively assess the success of restoration practices implemented in woodlands along the Dabao Highway in Longitudinal Range-Gorge Region of Yunan Province.

\section{Species composition}

It was reported by several researchers (Lockwood and Pimm, 1999; Smith et al., 2000) that species composition can reflect the process of vegetation succession and be used as one of the objectives of vegetation restoration and improvement. The proportion of native species in the composition was a very important indicator for assessing the success of the restoration practice (Bradshaw, 1996; Hobbs and Norton, 1996). The number and abundance of species of the climax community may also be important for the success of restoration, which can be assessed by using reference sites. However, the development of the species composition in restored sites toward a state that resembles the appropriate reference sites was, at best, extremely slow and may not eventuate at all. And, if succession does occur, the time scale required for restored sites to match the target state may range from several decades to the centuries (Anand et al., 2005).

The results from current study show that the community in RP I was a pure stand of E. maideni, an introduced commercial tree. Our observations suggest that shading of this fast-growing plant suppressed the growth and abundance of other species. This is consistent with Brown and Bugg's finding (2001) that transplanted forbs with immediately adjoining perennial grasses grew better if the former was in full sunlight than if overtopped by the adjacent perennial grass. Weeding management of the commercial forests might have contributed to the pure stands of E. maideni, but local residents said that weed control was done infrequently. The pure stand of $\mathrm{E}$. maideni has high economic value for oil and compound production. Risk of death or degradation from environmental stress (draught, frost, disease etc.) and disturbance (fire, logging etc.) might impose a risk with the extensive use of this species in forest restoration and improvement projects. Moreover, non-native species may not fulfill the same function as native species (Jordan et al., 1996).

The RPII plot was replanted with the native tree, $P$. yunnanensis, the same year that RPI was planted, but many more species were found in the RPII plots due to less shade suppression of new seedlings of this slowgrowing plant. At early stages of succession, pioneer plants of perennial grasses and annual weeds can grow very well under high light conditions, which may account for the high proportion of exotic plants and herbs in these plots. Although the proportion of shrubs and trees was not high, the data suggest that there is a potential for restoring the damaged lands into natural woodlands.

The RPIII plot was reforested in 2002, two years before RPI and RPII, with a combination of P. yunnanensis and Alnus nepalensis, the two dominant species of the primary vegetation in this site as recorded in literature (Wu, 1980). Although the plant community was still dominated by pioneer herb species at the early stages of succession, the proportion of exotic plants decreased dramatically. In comparison, in the RPIV plot planted solely with P. yunnanensis in the same year, there was a low number of species due to the fact that there were few herbs. This may be attributed to interspecific competition or allopathic interactions with neighboring plants within the community, which needs to be studied further. As concluded by Cairns (1996), the species composition matters during vegetation restoration or improvement.

In the RPV plot planted with P. yunnanensis in 1999, the first year the national policy of "Returning Agricultural Land to Forest Land" was implemented, native plants took an important position, community and woody plants increased in proportion to herbs over time as succession progressed. In the RPVI plot planted with P. yunnanensis in 1995, five years earlier than RPV was reforested, more trees were found in the species composition of secondary vegetation. It can be concluded from the decreased proportion of exotic plants and herbs in these plots that the vegetation was progressing through succession. These two reforestation strategies can speed up natural restoration processes of the vegetation to some extent.

The naturally restored plot of RPVII was rich in the total number of species, woody species and herbaceous species, and the proportion of native species was high. Thus, it may be concluded that, with time, the degraded woodlands can recover from their seed pool in the soil. Because the vegetation in the RPVIII plot was in the early stages of restoration, the species composition was much simpler and was dominated by herbaceous pioneer species. Although the species composition of the naturally restored and planted communities was not entirely the same, common species were found in both treatments (except for RPI). The same finding was reported by Reay and Norton (1999) in a restored temperate of New Zealand rainforest. These authors stated that there was a similarity in the composition of tree regeneration (that is, individuals recruited after the original plantings) 
between the restored sites and an older naturally regenerating site. Both of these findings illustrate that alternative ways can be used in successful restoration and improvement efforts in terms of the restoration and improvement efforts in terms of the species composition.

\section{Plant cover}

Plant cover is effective in preventing erosion to the extent that it absorbs the kinetic energy of raindrops, covers a large proportion of the soil during periods of the year when rainfall is heavy, slows down runoff, and keeps the soil surface porous (Zhang et al., 2005). Whatever the slope, cropping technique, extent of soil fragility or climatic conditions, complete plant cover ensures a high level of soil and water conservation. Plant cover may have a priority in any effort to improve water management, infiltration, biomass production and soil conservation. Some researchers have used plant cover as an indicator to assess ecosystem functional status in restoration projects (Maestre et al., 2006).

The fast growing non-native E. maiden in the RPI plot resulted in complete canopy cover with tall plants which have the potential for water conservation, but, conversely, the low soil surface cover (herbs or litter cover) may create problems of high surface runoff. In comparison, the RPVI plot had both high canopy cover and welldeveloped vegetation structure, and its function of water conservation may be higher. Although the replanted vegetation in the RPII, RPIV and RPVII plots were relatively low in canopy cover, the well-developed structure of the plant communites might increase their water conservation function. The plant cover of the naturallyrestored community in the RPVIII plot was quite, which may decrease its water conservation function.

Plant cover can be used to compare the abundance (dominance) of species of widely different growth forms, because it is not biased by the size and distribution of individuals (Mueller-Dombois and Ellenberg, 1974; Whitaaker, 1975). The results of functional groups cover in this study indicate that in the early stages of reforestation, herbs dominated the plant community in most plots (except RPI), and woody plants became more important with time after reforestation. In addition, the reforestation strategy can affect the plant cover of the different functional groups, and thus affect their dominance in the community.

Plant height can reflect the growth rate of vegetation, which may be partly associated with plant cover. It is evident that the vegetation in the plot of RPI reforested with the fast-growing plant, E. maideni, was much higher in plant cover and that in the RPII reforested with the slow-growing tree, $P$. yunnanensis. Although some researchers reported that ground cover thins with age, since restoration plantings increase due to competitive interactions between the growing tree stratum and the dense largely exotic ground cover of the restored vegetation (Wilkins et al., 2003). It was found in this study that taller vegetation increased with age, since restoration in RPVI resulted in higher plant cover. If our findings can be further tested, plant height might be used as an auxiliary indicator of plant cover to assess ecosystem functional status in restoration projects.

\section{Species diversity}

Species diversity components were used by some researchers to assess ecosystem restoration success (Jordan et al., 1996; Anand et al., 2005; Martin et al., 2005). Species diversity has two components (Stirling and Wilsey, 2001): evenness (how evenly abundance or biomass is distributed among species) and richness (number of species in unit area). High evenness can increase invasion resistance, total and below-ground productivity, and can reduce local plant extinction rates (Wilsey and Polley, 2002, 2004; Smith et al., 2004). Species richness and recruitment were found either negatively or positively correlated in a number of saturation studies in grasslands (Tilman, 1997; Levine, 2000; Franzén, 2001). It was also concluded by some researchers (Brown and Bugg, 2001) in grassland restoration studies that there may be challenges to establishing multiple grass and forb species, although initial species richness can be controlled in restoration projects.

It was found in this study that species diversity of the plant community varied with the reforestation practice and time. Natural restoration (RPVII) or reforestation with native dominant plants (RPIII and RPVI) can lead to high species diversity by the 3rd or 4th year following planting. High species richness of the naturally restored community of RPVII implies that there was a positive relationship between richness and natural restoration. In contrast to Sluis's finding (2002), a decrease in species richness was not observed in our study. Two communities, either totally planted with native dominant plants but in the early years since restoration (RPIII), or partly planted with native dominant plants but in later years since restoration (RPVI), were high in species evenness. These two plant communities may have high invasion resistance, and high total and below-ground productivity according to previous researcher's findings cited before.

In the past, several studies of grassland restoration practices found that diversity and richness were much lower in the restored than remnant sites (Kindscher and Tieszen, 1998; Sluis, 2002; Martin et al, 2005), and comparisons between restored and remnant sites revealed no differences in evenness (Kindscher and Tieszen, 1998; Martin et al., 2005). In the present study, such comparisons were not possible, as there were no remaining reference or remnant sites. However, the preliminary conclusion that can be drawn by comparing 
species diversity between the different reforestation strategies that natural restoration or reforestation with native dominant trees are reasonable choices for vegetation restoration or improvement.

Because the native woodlands were dominated by woody plants in the past, the colonization of these species is of particular interest. In the present study, it was found that species diversity of functional groups indicates that diversity and richness of herbs was generally higher than that of shrubs and trees under different reforestation practices, whereas species evenness of woody plants was greater than that of herbs in some cases. This implies that small-scale species evenness may be more easily restored than species richness. This result can further support Martin et al. (2005) finding from a grassland restoration study that small-scale evenness may be easier to restore than richness.

\section{Conclusion}

The different reforestation treatments had significant effects on species composition, plant cover and species diversity, and thus affected the ecological function of plant communities. Therefore, decisions and regulations related to reforestation strategies, such as re-vegetation planning, species selection, seedling management should be carefully considered before implementation. Reforestation with native dominant woody plants or natural restoration is a reasonable choice for reforestation projects implemented in areas along the roadside of Dabao Highway, Longitudinal Range-Gorge Region of Yunan Province, China. Our conclusions have important implications for national and regional policies governing the regulation of ecosystem restoration and improvement.

\section{ACKNOWLEDGEMENTS}

This research is supported by China National Key Subject (NKBRSF project 2003CB415104) and National Natural Science Foundation of China (NSFC 40701173). The authors wish to express great thanks to reviewers and editors for their time and efforts.

\section{REFERENCES}

Anand M, Laurence S, Rayeield B (2005). Diversity relationships among taxonomic groups in recovering and restored forests. Conservation Biology 19: 955-962.

Bradshaw AD (1996). Underlying principles of restoration. Canadian J. of Fisheries and Aquatic Sci. 53 (Supplement 1): 3-9.

Brown CS, Bugg AL (2001). Effects of established perennial grasses on introduction of native fobs in California. Restoration Ecology. 9(1): 3848.

Cairns J (1996). Disturbed ecosystems as opportunities for research in restoration ecology. In: Jordan III WR, Gilpin ME, Aber JD (eds) Restoration ecology: a synthetic approach to ecological research. Cambridge University Press, Cambridge, United Kingdom. pp. 307320.
Davenport DW, Breshears DD, Wilcox BP (1998). Viewpoint: sustainability of piñion-juniper ecosystems - a unifying perspective of soil erosion thresholds. J. of Range Management 51: 231-240.

Dong M (eds) (1997). Methods in surveying and analyzing terrestrial biological Communities China Standard Press, Beijing, China.

Franzén D (2001). The role of species richness for recruitment in a seminatural grassland. Oikos 95: 409-415.

Gao MC (2003). Elementary Discussion on Soil and Water Loss and Desertification of Yunnan. Yunnan Environ. Sci. 25 (Supplement 1): 117-120.

He YW (1991). Soil erosion and vegetation restoration. J. W. China For. Sci. 12(2): 8-11.

Hobbs RJ, Norton DA (1996). Towards a conceptual framework for restoration ecology. Restor. Ecol. 4: 93-110.

Huang H, Luo YF, Chen ZY (2001). SPSS 10.0 for windows: Statistic analysis. Beijing: People's Posts and Telecommunications Press.

Jordan III WR, Gilpin ME, Aber JD (1996). Restoration ecology: a synthetic approach to ecological research. Cambridge University Press, Cambridge, United Kingdom.

Kindscher K, Tieszen LL (1998). Floristic and soil organic matter changes after five and thirty-five years of native tallgrass prairie restoration. Restor. Ecol. 6: 181-196.

Kruse BS, Groninger JW (2003). Vegetative Characteristics of Recently Reforested Bottomlands in the Lower Cache River Watershed, Illinois, U.S.A. Restor. Ecol. 11: 273-280.

Levine JM (2000). Species diversity and biological invasions: relating local process to community pattern. Science 288: 852-854.

Liu HM (2005). Problems and Countermeasures Related to Forestry Ecology Development in Yunnan Province. J. Southwest For. Coll. 25(1): 6-9.

Liu XP, Guo HJ, Gao CH (2002). Strategies for Sustainable Development in Nujiang Valley of Yunnan Province. Rural Ecoenviron. 22(4): 49-52.

Lockwood JL, Pimm SL (1999). When Does Restoration Succeed? In: Weiher E, Keddy $\mathrm{P}$ (eds) Ecological assembly rules: perspectives, advances, retreats. Cambridge University Press, Cambridge, UK. pp. 363-392.

Maestre FT, Cortina J, Vallejo R (2006). Are Ecosystem Composition, Structure, and Functional Status Related to Restoration Success? A Test from Semiarid Mediterranean Steppes. Restor. Ecol. 14: 258266.

Martin L, Moloney KA, Wilsey BJ (2005). An assessment of grassland restoration success using species diversity components. J. Appl. Ecol. 42: 327-336.

Martin LM, Wilsey BJ (2006). Assessing grassland restoration success: relative roles of seed additions and native ungulate activities. J. Appl. Ecol. 43: 1029-1043.

McCracken JR, Abaza H (2001). Environmental valuation: a worldwide compendium of case studies. Earthscan, London, UK.

Mueller-Dombois D, Ellenberg H (1974). Aims and methods of vegetation ecology. Wiley, New York.

Myers N (1996). Environmental services of diversity. Proc. Natl. Acad. Sci. 93: 2764-2769.

Oliver CD, Larson BC (1996). Forest stand dynamics, update edition. John Wiley \& Sons, New York.

Palmer MA, Ambrose RF, Poff NL (1997). Ecological theory and community restoration ecology. Restor. Ecol. 5: 291-300.

Peng LB, Wang HP (2005). On the problems existing in ecological environment construction in Yunnan and the solution to the problems. Yunnan Geogr. Environ. Res. 17 (Supplement 1): 46-49.

Polley HW, Derner JD, Wilsey BJ (2005). Patterns of Plant Species Diversity in Remnant and Restored Tallgrass Prairies. Restor. Ecol. 13: 480-487.

Pywell RF, Bullock JM, Roy DB (2003). Plant traits as predictors of performance in ecological restoration. J. Appl. Ecol. 40: 65-77.

Reay SD, Norton DA (1999). Assessing the success of restoration plantings in a temperate New Zealand forest. Restor. Ecol. 7: 298308.

Reynolds JR, Smith MS (eds) (2002). Global desertification: do humans cause deserts? Vol. DWR 88 Dahlem Workshop Report, Berlin, Germany.

Sisk T, Launer AE, Switky KR (1994). Identifying extinction threats: Glo- 
bal analyses of the distribution of biodiversity and the expansion of the human enterprise. BioScience. 44: 592-604.

Sluis WJ (2002). Patterns of species richness and composition in recreated grassland. Restor. Ecol. 10: 677-684.

Smith MD, Wilcox JC, Kelly $T$ (2004). Dominance not richness determines invasibility of tallgrass prairie. Oikos 106: 253-262.

Smith RS, Shiel RS, Bardgett, RD (2003). Soil microbial community, fertility, vegetation and diversity as targets in the restoration management of a meadow grassland. J. Appl. Ecol. 40: 51-64.

Smith RS, Shiel RS, Millward D (2000). The interactive effects of management on the productivity and plant community structure of an upland meadow: an 8-year field trial. J. Appl. Ecol. 37: 1029-1043.

Stirling G, Wilsey B (2001). Empirical relationships between species richness, evenness, and proportional diversity. Am. Nat. 158: 286299.

Thurow TL (1991). Hydrology and erosion. In: Heitschmidt PK, Stuth JW (eds) Grazing Management- an ecological perspective. Timber Press, Portland, Oregon, USA.

Tilman D (1997). Community invasibility, recruitment limitation, and grassland biodiversity. Ecology. 78: 81-92.

Tivy J (1990). Agricultural ecology. Longman Scientific and Technical Press, New York, USA.

Wang HY, Shi SS (2001). Water and Soil Erosion Resulted From Road Building in Yunnan. Yunnan Environ. Sci. 19(1): 45-46, 55.

Wang RP, Gao ZQ (2001). Land system and ecological-environmental problem of agriculture. J. Shanxi Agric. University (Natural Science Edition) 24(4): 15-17.

Wang YS (1999). Household Responsibility System, Behavior of Farmers and Environmental Problems in China's Agriculture. J. Peking University (Humanities and Social Sciences). 43(3): 43-50, 157

Whisenant SG (1999). Repairing damaged woodlands: a processingoriented, landscape-scale approach. Cambridge University Press, UK
Wilkins S, Keith DA, Adam P (2003). Measuring Success: Evaluating the Restoration of a Grassy Eucalypt Woodland on the Cumberland Plain, Sydney, Australia. Restor. Ecol. 11: 489-503.

Wilsey BJ, Polley HW (2002). Reductions in species evenness increase dicot seedling invasion and spittle bug infestation. Ecol. Lett. 5: 676684.

Wilsey BJ, Polley HW (2004). Realistically low species evenness does not alter grassland-species richness-productivity relationships. Ecology. 85: 2693-2701.

World Bank (2002). Linking poverty reduction and environmental management: policy challengers and opportunities. Department for International Development of European Commission, United Nations Development Programme and World Bank, Washington, D.C.

Wu ZY (eds) (1980). Yunnan Vegetation. Scientific Press, Beijing, China.

Zhang XM, Yu XX, Wu SH (2005) Effect of forest vegetation on runoff and sediment production in sloping lands of Loess area. Frontiers of Forestry in China. 1(3): 336-342.

Zhao GY (2006). Ecological Environmental Protection and Pollution Control Measures in Constructing Highway in Yunnan. Yunnan Environ. Sci. 26 (Supplement 1): 65-66. 